\title{
Penerapan Model Paired Storytelling dalam Pembelajaran Bercerita
}

\section{Suryaning Hesti Resmi*}

\section{A R T I C L E I N F O}

Article history:

Received 19 February 2019

Received in revised form 30 March 2019

Accepted 10April 2019

Available online 20 May 2019

Kata Kunci:

Model pembelajaran paired storytelling, pembelajaran bercerita

Keywords:

Paired storytelling

learning model,

storytelling learning

\begin{abstract}
A B S T R A K
Penelitian ini bertujuan, mengetahui bagaimana penerapan model Paired Storytelling untuk meningkatkan motivasi belajar siswa kelas V SD Negeri Kumendung Rembang, mengetahui kelebihan, kekurangan, kendala penerapan model Paired Storytelling pada siswa kelas V SD Negeri Kumendung Rembang. Penelitian ini merupakan penelitian kualitatif. Subjek penelitian diambil dari siswa kelas $V$ sebanyak 30 orang. Teknik pengumpulan data menggunakan Nonprobability Sampling. Data dalam penelitian ini diperoleh melalui observasi, dokumentasi, dan tes. Setting penelitian ini di SD Negeri Kumendung Rembang. Hasil penelitian menunjukkan bahwa, Penerapan model paired storrytelling dalam pembelajaran bercerita oleh kelompok 1 mendapat prosentase $80 \%$, Kelompok 2 mendapat prosentase $65 \%$, Kelompok 3 mendapat prosentase $75 \%$, Kelompok 4 mendapat prosentase $80 \%$. Kelompok 5 mendapat prosentase $70 \%$, Kelompok 6 mendapat prosentase $75 \%$, Kelompok 7 mendapat prosentase $75 \%$, Kelompok 8 mendapat prosentase 55\%, Kelompok 9 termasuk mendapat prosentase $80 \%$, serta penerapan model paired storrytelling dalam pembelajaran bercerita oleh kelompok 10 mendapat prosentase $65 \%$. Dengan demikian diatas dapat disimpulkan bahwa penerapan model paired storrytelling mampu meningkatkan motivasi belajar siswa kelas $\mathrm{V}$ SD Negeri Kumendung Rembangpada kelas V SD Negeri Kumendung Rembang
\end{abstract}

\section{A B S T R A C T}

This study aims to find out how the application of the Paired Storytelling model to improve the learning motivation of fifth grade students of SD Negeri Kumendung Rembang, to know the advantages, disadvantages, and constraints of applying the Paired Storytelling model to fifth grade students of SD Negeri Kumendung Rembang. This research is a qualitative research. The research subjects were taken from class $V$ students as many as 30 people. Data collection techniques using Nonprobability Sampling. The data in this study were obtained through observation, documentation, and tests. The setting of this study is at SD Negeri Kumendung Rembang. The results showed that, the application of paired storrytelling models in storytelling learning by group 1 got a percentage of $80 \%$, Group 2 received a percentage of $65 \%$, Group 3 received a percentage of $75 \%$, Group 4 received a percentage of $80 \%$. Group 5 gets a percentage of $70 \%$, Group 6 gets a percentage of $75 \%$, Group 7 gets a percentage of 75\%, Group 8 gets a percentage of 55\%, Group 9 includes a percentage of $80 \%$, and application of paired storrytelling models in storytelling learning by group 10 gets a percentage of $65 \%$. Thus, it can be concluded that the application of paired storrytelling models can improve the learning motivation of fifth grade students of SD Negeri Kumendung Rembang in the fifth grade of Kumendung Rembang Elementary School. 


\section{Pendahuluan}

Bercerita merupakan kompetensi yang harus dipelajari, dipahami, dan dikuasai siswa. Kompetensi dasar bercerita tersebut terdapat pada kurikulum K13 dengan Tema 3, Makanan Sehat Pembelajaran ke 1, Subtema 2, Pentingnya Makanan Sehat Bagi Tubuh. Dengan demikian, siswa diharapkan mampu bercerita dengan baik.

Bercerita merupakan sarana untuk menuju mahir berbicara (Mariana, 2015). Akan tetapi, keadaan pembelajaran bahasa Indonesia di sekolah-sekolah belum membawa siswa ke arah pencapaian kemahiran tersebut. Tampaknya kenyataan itu tidak jauh berbeda dengan kenyataan yang terjadi dalam proses pembelajaran bahasa Indonesia di SD Negeri Kumendung Rembang. Tujuan utama berbicara adalah untuk berkomunikasi. Komunikasi merupakan pengiriman dan penerimaan pesan atau berita antara dua orang atau lebih sehingga pesan yang dimaksud dapat dipahami. (Ningsih, 2014). Bercerita sangat bermanfaat sekali bagi guru, bercerita dapat menjadi motivasi untuk mengembangkan daya kesadaran, memperluas imajinasi anak, orang tua atau menggiatkan kegiatan bercerita pada berbagai kesempatan. Maksud pada berbagai kegiatan misalnya pada saat anak-anak sedang bermain, anak menjelang tidur atau guru sedang membahas tema dengan menggunakan metode bercerita (Nurhayani, 2017).

Berdasarkan wawancara yang dilakukan dengan guru kelas V SD Negeri Kumendung Rembang dapat dikemukakan fakta-fakta sebagai berikut.

Guru mengakui selama pembelajaran menceritakan, hanya menyuruh siswa tampil satu kali dalam satu semester karena keterbatasan waktu. Hal itu dilakukan dengan cara siswa diminta ke luar kelas untuk mencari narasumber cerita sebagai bahan untuk menceritakan hasil di depan kelas. Setelah siswa kembali, guru menawarkan pada siswa untuk maju di depan kelas. Sebelumnya. Siswa tidak diberikan latihan secara intensif. Menurut pendapat guru ketika siswa mendengarkan cerita orang lain, tentunya ia akan bertanya saat ia belum jelas tentang cerita yang didengarnya. Guru juga menuturkan proses siswa bertanya adalah proses bercerita. Selain itu, siswa lebih bebas untuk mengungkapkan cerita dalam pikirannya.

Guru mengamati tidak semua siswa berani maju di depan kelas. Hampir semua siswa saling menyuruh temannya tampil di depan kelas. Hanya siswa terentu yang berani untuk tampil di depan kelas. Rasa malu dan takut salah satu untuk tampil di depan kelas itu biasanya disebabkan oleh: 1) tidak biasanya siswa menggunakan bahasa Indonesia untuk berkomunikasi dalam kehidupan sehari-hari, 2) takut dimarahi guru jika salah bicara, 3) minim kosa kata bahasa Indonesia, 4) kurang percaya diri untuk berbicara di depan teman-temannya.

Berdasarkan pengamatan guru, siswa belum terampil dalam bercerita. Ketika berdiri di depan kelas awalnya siswa lancar dalam bercerita, lambat laun mereka terbata-bata dalam mengucapkan kalimat demi kalimat. Bahkan, sesekali mereka diam karena lupa jalan ceritanya. Selain itu, terkadang mereka masih menggunakan bahasa daerah. Ketika ditanya mengapa hal itu terjadi mereka mengatakan bahwa pada dasarnya cerita yang akan dituturkan kembali ada tetapi mereka susah mengatakannya. Selain itu, banyak yang menunduk ketika bercerita. Mereka tidak berani menatap teman-temannya. Mereka terlihat malu. Di samping itu, mereka gugup. Volume suara mereka mengecil, ada yang gemetar, ekspresi mereka kaku. Guru cukup lama menunggu mereka memulai lagi bercerita. Hal itu menyebabkan siswa lain tidak mempunyai kesempatan untuk bercerita di depan kelas.

Siswa tampak tenang mengikuti pelajaran verbalisme yang terjadi bila guru terlalu banyak menggunakan kata-kata dalam menjelaskan pelajaran, apalagi kata yang digunakan terasa asing bagi siswa sehingga inti yang sama bisa ditafsirkan berbeda. Makna yang keliru konsep akan dibawa siswa untuk waktu yang relatif lama. Beberapa siswa tampak tenang mengikuti pelajaran dan tidak menimbulkan kesulitan bagi guru. Namun, setelah guru mengajukan persoalan terjadi kesulitan siswa untuk menjawabnya. Hal ini karena siswa kurang tertarik pada proses pembelajaran kemudian lari ke dunia angan-angannya. Hal ini sangat disadari guru SD N Kumendung Rembang.

Selanjutnya, pada tahap penilaian guru mengakui bahwa penilaian pembelajaran hanya didasarkan pada nilai sepuluh siswa yang mempunyai kesempatan untuk tampil bercerita di depan. Jika nilai sepuluh siswa yang telah tuntas, guru menganggap pembelajaran bercerita itu telah berhasil. Siswa yang tidak tampil dianggap sudah mencapai ketuntasan belajar.

Hal tersebut merupakan beberapa penghambat kemampuan siswa untuk bercerita di depan kelas. Untuk itu, perlu adanya model, teknik, metode, atau strategi pembelajaran yang baru, untuk meningkatkan kepercayaan diri dan kemampuan siswa dalam bercerita. Melalui model paired storytelling dapat membantu memudahkan siswa untuk mengekpresikan wawasannya dan menarik perhatian siswa terhadap proses pembelajaran.

Dalam pembelajaran berbicara terdapat model pembelajaran yang dapat diterapkan. Contoh model pembelajaran berbicara adalah sidang umum, sidang pleno, kerja kelompok, kelompok minat khusu, 
forum penyajian situasi, penyajian konflik, penyajian skill, brainstormin, buzz group, case study, croser over group. Adapun teknik yang dapat digunakan dalam pembelajaran berbicara, seperti ceramah (penjelasan), bertanya, demonstrasi, storytelling, berpasangan, sosio-drama. Boleh juga mengadaptasi dengan model serta strategi. Berbagai model pembelajaran memang perlu dicari, atau diciptakan. Paling tidak model yang telah diciptakan itu diadaptasi dan disesuaikan lalu diujicobakan dahulu. Mengingat, telah diketahui bahwa jiplakan model yang dibuat orang lain belum tentu cocok untuk diterapkan dalam situasi dan kondisi psikososekpoltek kita. Maka penelitian-penelitian tentang model pembelajaran untuk mengembangkan kemahiran berbicara (bercerita) yang sesuai dan saling menunjang sangat diperlukan. Menurut Roestiyah (2008:159), pada hakikatnya model yang paling tepat untuk setiap mata pelajaran itu sukar ditentukan. Begitu juga sukar menggunakan salah satu metode atau model saja secara murni.

\section{Metode}

Jenis penelitian ini adalah penelitian deskripif kualitatif, karena dalam menyimpulkan materi hasil analisis menggunakan kata-kata bukan dengan menggunakan angka, sedangkan tehnik pengumpulan datanya melalui analisis data. Menurut Moleong (2014: 6) penelitian kualitatif adalah penelitian yang bermaksud untuk memahami fenomena tentang apa yang dialami oleh subjek penelitian misalnya seperti perilaku, persepsi, motivasi, tindakan, dll., secara holistik, dan dengan cara deskripsi dala bentuk katakata dan bahasa, pada suatu konteks khusus yang alamiah dan dengan memanfaatkan berbagai metode alamiah.

Dalam penelitian deskriptif kualitatif, data yang dikumpulkan adalah data yang berupa kata-kata, gambar, dan bukan angka-angka. Data tersebut dapat dimungkinkan berasal dari naskah wawancara, catatan lapangan, foto, videotape, dokumen pribadi, catatan atau memo, dan dokumen resmi lainnya. Dengan demikian, laporan penelitian akan berisi kutipan-kutipan data untuk memberi gambaran penyajian laporan tersebut. (Moleong, 2014:11).

Teknik pengumpulan data merupakan langkah yang paling utama dalam penelitian, Karena tujuan utama dari penelitian adalah mendapatkan data (Sugiyono, 2015:308). Teknik pengumpulan data yang digunakan dalam penelitian ini adalah :

1. Observasi

Penelitian ini menggunakan teknik pengumpulan data observasi partisipatif pasif untuk mengamati penerapan model paired storrytelling pada kelas V SD Negeri Kumendung Rembang. Observasi ini bertujuan untuk mengumpulkan data-data yang berkaitan dengan penerapan model paired storrytelling pada kelas V SD Negeri Kumendung Rembang.

2. Dokumentasi

Instrumen dokumentasi diperoleh peneliti dari data-data terkait siswa, guru, dan sarana prasarana sekolah. Dan untuk mengumpulkan data foto atau kegiatan pembelajaran sebagai bukti bahwa sudah melakukan penelitian.

3. Tes

Teknik pengumpulan data ini dalam bnetuk tes penelitian ini yaitu berupa pretest. Tes lisan yang digunakan dalam penelitian ini yaitu yang mewajibkan siswa dapat bercerita secara langsung di depan kelas setiap individu untuk dapat berpendapat tentang diskusi yang dibahas pada hari penelitian. Tes dalam penelitian ini mengetahui keterampilan bercerita siswa untuk dapat diteliti guna untuk melihat apakah ada pengaruh pada pembelajaran dengan menerapkan model Paired Storytelling.

\section{Hasil dan Pembahasan}

\section{Deskripsi Lokasi Penelitian}

SD Negeri Kumendung beralamat di Desa Kumendung Kecamatan Rembang Kabupaten Rembang Provinsi Jawa Tengah. Lokasi sekolah berada tepat ditengah pemukiman warga dan jalan utama Desa Kumendung.Jumlah guru SD Negeri Kumendung adalah 10 orang dengan kepala sekolah bernama Bapak Selamet Sujiharno S.Pd. Jumlah siswa di SD Negeri Kumendung adalah sebanyak 183 orang siswa yang terdiri dari 98 siswa laki-laki dan 85 siswi perempuan. Bangunan sekolah cukup luas, terdiri dari 6 ruang kelas dan 1 kantor guru. Selain itu juga terdapat musholla, ruang perpustakaan, ruang UKS dan ruang serbaguna yang biasa digunakan sebagai tempat pertemuan dengan wali murid.

Reduksi Data

Berdasarkan data yang diperoleh, ada banyak masalah yang terjadi di sekolah. Masalah-masalah tersebut diantaranya yaitu berkaitan dengan sarana dan prasarana sekolah, keaktifan siswa dalam pembelajaran dan masalah keterampilan belajar khususnya keterampilan bercerita. Dalam penelitian ini masalah yang akan diteliti lebih lanjut yaitu berkaitan dengan penerapan model paired storytelling dalam 
pembelajaran bercerita. Masalah ini penting untuk diteliti, karena dalam setiap pembelajaran siswa dituntut untuk dapat bercerita secara baik dan kualitas cerita yang dibawakan menentukan kualitas siswa tersebut (Mulyasa, 2015: 70).

\section{Penyajian Data}

Penyajian data dilakukan setelah penelitian di lapangan selesai. Data yang disajikan meliputi hasil pengamatan dan penelitian. Untuk hasil pengamatan dan penelitian mengenai penerapan model paired storrytelling dalam pembelajaran bercerita dilakukan penyajian data sebanyak 10 kelompok. Kelompok tersebut terdiri dari 30 sampel (siwa kelas 5), dimana masing-masing kelompok berjumlah 3 orang siswa.

Peneliti menyajikan dalam bentuk tabel, diagram batang, dan uraian singkat. Data diperoleh dari lembar pengamatan penerapan model paired storrytelling dalam pembelajaran bercerita, yang diperkuat dengan hasil penelitian terhadap siswa. Peneliti melakukan kegiatan pengamatan di kelas V SD Negeri Kumendung Rembang. Jumlah sampel yang akan diteliti adalah 30 siswa kelas $\mathrm{V}$ yang dibagi menjadi 10 kelompok, masing-masing kelompok terdiri dari 3 siswa. Berikut adalah data siswa yang akan diteliti, yaitu :

Tabel 1. Data sampel yang akan diteliti

\begin{tabular}{|c|c|c|c|c|}
\hline No. & Nama Kelompok & Nama Siswa & Jenis Kelamin & Usia \\
\hline \multirow{4}{*}{1} & & Aqila Nanda & $\mathrm{P}$ & 10 \\
\hline & Kelompok 1 & Alvia Putri U. & $\mathrm{P}$ & 12 \\
\hline & & Lina Widya & $\mathrm{P}$ & 12 \\
\hline & & Afrida Lestari & $\mathrm{P}$ & 12 \\
\hline \multirow[t]{3}{*}{2} & Kelompok 2 & Evan Ardiansyah & $\mathrm{L}$ & 11 \\
\hline & & Azam Maulana & $\mathrm{L}$ & 10 \\
\hline & & Afif Muhammad & $\mathrm{L}$ & 11 \\
\hline \multirow[t]{3}{*}{3} & Kelompok 3 & Agus Hermanto & $\mathrm{L}$ & 11 \\
\hline & & Alvi Yuniar & $\mathrm{P}$ & 11 \\
\hline & & Yola Pramudita A. & $\mathrm{P}$ & 11 \\
\hline \multirow[t]{3}{*}{4} & Kelompok 4 & Zanuar Alvianto & $\mathrm{L}$ & 10 \\
\hline & & Neta Kusuma W. & $\mathrm{P}$ & 11 \\
\hline & & Devi Amalia & $\mathrm{P}$ & 11 \\
\hline \multirow[t]{3}{*}{5} & Kelompok 5 & Ifta Khusniati & $\mathrm{P}$ & 12 \\
\hline & & Hanif Magfiroh & $\mathrm{P}$ & 12 \\
\hline & & Fendy Riyandy & $\mathrm{L}$ & 12 \\
\hline \multirow[t]{3}{*}{6} & Kelompok 6 & Slamet Wahyudi & $\mathrm{L}$ & 10 \\
\hline & & Dian Handayani & $\mathrm{P}$ & 12 \\
\hline & & Arif Miftah & $\mathrm{L}$ & 12 \\
\hline \multirow[t]{3}{*}{7} & Kelompok 7 & Muhammad Sandeli & $\mathrm{L}$ & 11 \\
\hline & & Fadhillah & $\mathrm{P}$ & 11 \\
\hline & & Fida Auliya Sari & $\mathrm{P}$ & 11 \\
\hline \multirow[t]{3}{*}{8} & Kelompok 8 & Winda Aulia & $P$ & 11 \\
\hline & & Cholid Fadlillah & $\mathrm{L}$ & 11 \\
\hline & & Muhammad Yusrul & $\mathrm{L}$ & 11 \\
\hline \multirow[t]{3}{*}{9} & Kelompok 9 & Akrom Syaifudin & $\mathrm{L}$ & 10 \\
\hline & & Naila Himma S. & $\mathrm{P}$ & 11 \\
\hline & & Yunita Putri & $\mathrm{P}$ & 11 \\
\hline \multirow[t]{2}{*}{10} & Kelompok 10 & Sigid Zuliyanto & $\mathrm{L}$ & 12 \\
\hline & & Eni Pratiwi & $\mathrm{P}$ & 11 \\
\hline
\end{tabular}

Sumber : Data Siswa Kelas 5 SD Negeri Kumendung

Berdasarkan Tabel 1 Data sampel yang akan diteliti, dapat diketahui bahwa jumlah murid lakilaki adalah sebanyak 13 siswa dan jumlah murid perempuan adalah sebanyak 17 siswa. Kemudian peneliti merencanakan pengamatan dan penelitian penerapan model paired storrytelling pada siswa kelas V SD Kumendung Rembang dengan jadwal pelaksanaan penelitian sebagai berikut: 
Tabel 2. Jadwal pelaksanaan penelitian

\begin{tabular}{lll}
\hline No. & Nama Kelompok & Tanggal Penelitian \\
\hline 1 & Kelompok 1 & 30 Oktober 2018 \\
2 & Kelompok 2 & 30 Oktober 2018 \\
3 & Kelompok 3 & 30 Oktober 2018 \\
4 & Kelompok 4 & 30 Oktober 2018 \\
5 & Kelompok 5 & 30 Oktober 2018 \\
6 & Kelompok 6 & 31 Oktober 2018 \\
7 & Kelompok 7 & 31 Oktober 2018 \\
8 & Kelompok 8 & 31 Oktober 2018 \\
9 & Kelompok 9 & 31 Oktober 2018 \\
10 & Kelompok 10 & 31 Oktober 2018 \\
\hline
\end{tabular}

Berdasarkan Tabel 2 Jadwal pelaksanaan penelitian, dapat diketahui bahwa pelaksanaan pengamatan dan penelitian penerapan model paired storrytelling dilaksanakan selama 2 hari mulai tanggal 30 Oktober 2018 sampai 31 Oktober 2018. Dimana pada dua hari tersebut dibagi 5 kelompok dalam satu hari, yaitu kelompok 1 sampai 5 pada tanggal 30 Oktober 2018 dan kelompok 6 sampai 10 pada tanggal 31 oktober 2018.

Hasil penelitian yang diperoleh dalam penerapan model paired storrytelling dalam pembelajaran bercerita pada siswa kelas 5 SD Negeri Kumendung yang dibagi menjadi 10 kelompok. Kemudian didapatkan hasil sebagai berikut:

Tabel 3. Rekapituasi skor hasil penelitian

\begin{tabular}{lllllllll}
\hline & & \multicolumn{7}{c}{ Skor } \\
No & Kelompok & Isi & Susunan & $\begin{array}{l}\text { Penggunaan } \\
\text { Bahasa }\end{array}$ & Pelafalan & Jumlah & Prosentase & Kriteria \\
\hline 1 & Kelompok 1 & 5 & 4 & 3 & 4 & 16 & $80 \%$ & Sangat Baik \\
2 & Kelompok 2 & 4 & 3 & 4 & 4 & 15 & $75 \%$ & Baik \\
3 & Kelompok 3 & 4 & 4 & 3 & 2 & 13 & $65 \%$ & Cukup \\
4 & Kelompok 4 & 4 & 4 & 4 & 4 & 16 & $80 \%$ & Sangat Baik \\
5 & Kelompok 5 & 5 & 3 & 4 & 2 & 14 & $70 \%$ & Baik \\
6 & Kelompok 6 & 5 & 4 & 3 & 3 & 15 & $75 \%$ & Baik \\
7 & Kelompok 7 & 4 & 3 & 4 & 4 & 15 & $75 \%$ & Baik \\
8 & Kelompok 8 & 3 & 2 & 3 & 3 & 11 & $55 \%$ & Kurang \\
9 & Kelompok 9 & 4 & 4 & 4 & 4 & 16 & $80 \%$ & Sangat Baik \\
10 & Kelompok 10 & 3 & 3 & 3 & 4 & 13 & $65 \%$ & Cukup \\
\hline
\end{tabular}




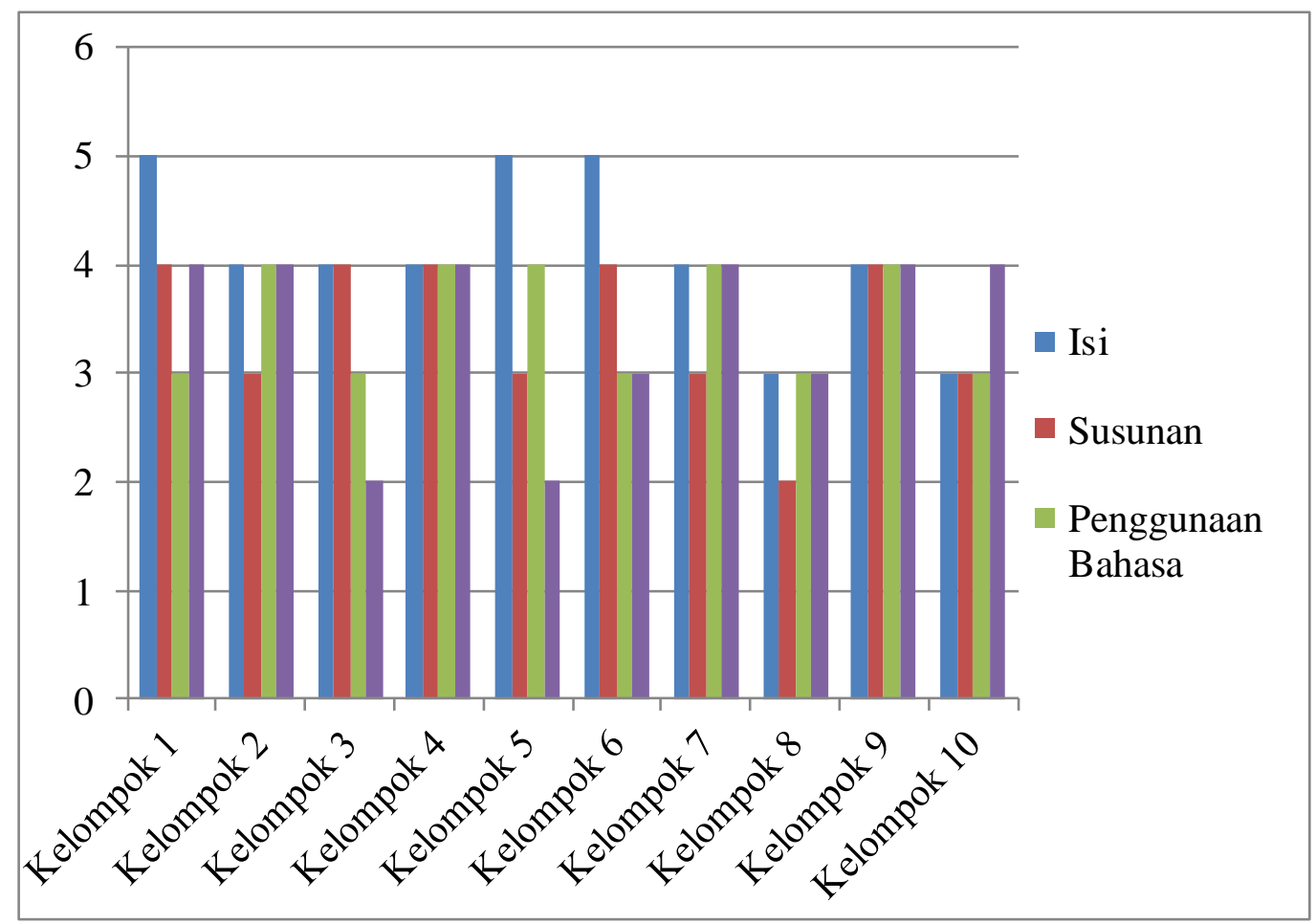

Gambar 1. Jumlah skor per indikator

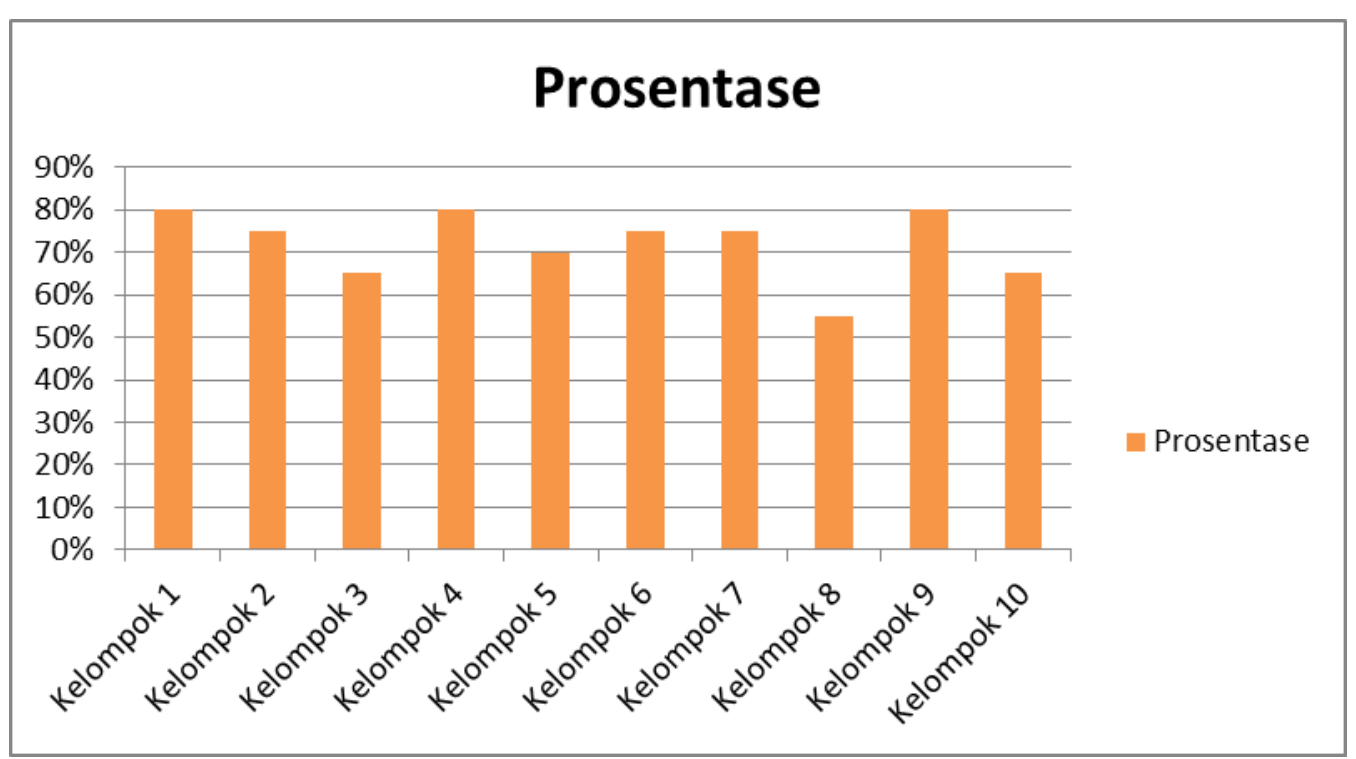

Gamber 2. Prosentase hasil skor 


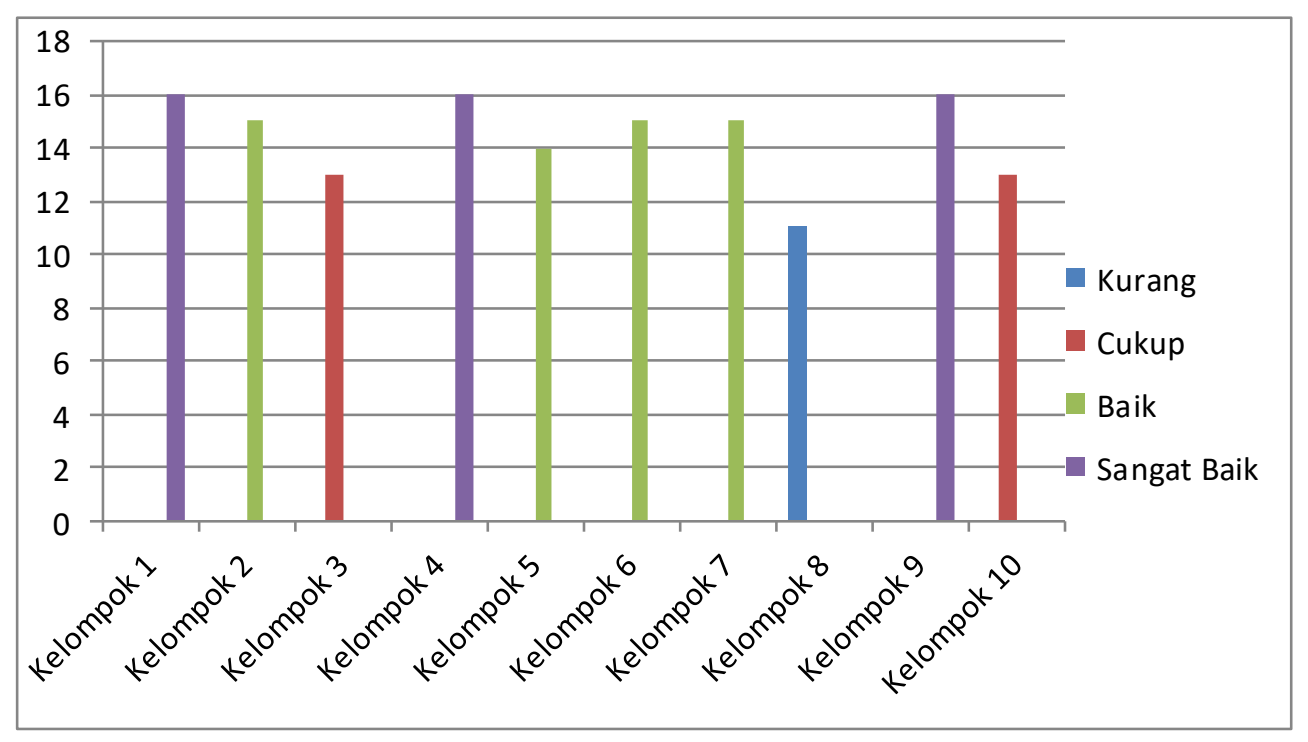

Gambar 3. Kategori hasil skor

\section{Simpulan Dan Saran}

Berdasarkan hasil penelitian diatas dapat disimpulkan bahwa penerapan model paired storrytelling mampu meningkatkan motivasi belajar siswa kelas V SD Negeri Kumendung Rembangpada kelas V SD Negeri Kumendung Rembang. Penerapan model paired storrytelling dalam pembelajaran bercerita oleh kelompok 1 mendapat prosentase 80\%, penerapan model paired storrytelling dalam pembelajaran bercerita oleh kelompok 2 mendapat prosentase $65 \%$, penerapan model paired storrytelling dalam pembelajaran bercerita oleh kelompok 3 mendapat prosentase $75 \%$, penerapan model paired storrytelling dalam pembelajaran bercerita oleh kelompok 4 mendapat prosentase $80 \%$. penerapan model paired storrytelling dalam pembelajaran bercerita oleh kelompok 5 mendapat prosentase $70 \%$, penerapan model paired storrytelling dalam pembelajaran bercerita oleh kelompok 6 mendapat prosentase $75 \%$, penerapan model paired storrytelling dalam pembelajaran bercerita oleh kelompok 7 mendapat prosentase $75 \%$, penerapan model paired storrytelling dalam pembelajaran bercerita oleh kelompok 8 mendapat prosentase 55\%, penerapan model paired storrytelling dalam pembelajaran bercerita oleh kelompok 9 termasuk mendapat prosentase $80 \%$, penerapan model paired storrytelling dalam pembelajaran bercerita oleh kelompok 10 mendapat prosentase 65\%.

Berdasarkan simpulan di atas, dapat disampaikan beberapa saran yaitu: 1. Bagi guru, dalam menerapkan model pembelajaran berbantuan media konkret pada proses pembelajaran dikelas perlu memahami langkah-langkah model pembelajaran inkuiri, serta memperhatikan: (a) Alokasi waktu diatur sebaik mungkin sehingga tiap tahapan pembelajaran dapat berlangsung secara optimal; (b) Pembagian kelompok harus benar-benar diperhatikan yakni secara heterogen berdasarkan jenis kelamin dan prestasi siswa; (c) Memberikan bimbingan individu dan kelompok secara merata; (d) Memahami sifat dan karakteristik anak, 2. Bagi siswa, siswa diharapkan berperan aktif dalam pembelajaran, memperhatikan penjelasan guru dan ikut terlibat dalam setiap kegiatan pembelajaran sehingga prestasi belajar akan meningkat serta diharapkan dapat berkerja secara mandiri maupun kelompok dan bertanggungjawab atas tugas yang diberikandan 3. Bagi Kepala Sekolah, diharapkan mengembangkan dan mengkaji lebih luas lagi model-model pembelajaran untuk mendukung proses belajar mengajar yang sesuai dengan kurikulum dan karakteristik anak meliputi sarana dan prasarana yang menunjang pembelajaran

\section{Daftar Rujukan}

Djiwandono, S. (2011). Tes Bahasa Pegangan Bagi Pengajar Bahasa. Malang: PT. Indeks.

Dibia, I.K., Dewantara, I.P.M. and Widiana, I.W., 2017. Pemberdayaan Teknik Bercerita Berbasis Budaya Bali Dalam Pembelajaran Keterampilan Menulis Karangan Pribadi Siswa Kelas V SD Mutiara Singaraja. Journal of Education Research and Evaluation, 1(2), pp.113-119. 
Fatimah, N., 2016. Implementasi cooperative learning tipe think-pair-share dalam pembelajaran bercerita di Sekolah Menengah Pertama. Jurnal Penelitian Humaniora, 16(2), pp.90-98.

Kaluas, I., Ismanto, A.Y. and Kundre, R.M., 2015. Perbedaan Terapi Bermain Puzzle Dan Bercerita Terhadap Kecemasan Anak Usia Prasekolah (3-5 Tahun) Selama Hospitalisasi Di Ruang Anak RS Tk. III. RW Mongisidi Manado. Jurnal Keperawatan, 3(2).

Kurniawati, Y. and Setyowati, S., 2014. Meningkatkan Kemampuan Berbicara Anak Melalui Metode Bercerita Dengan Media Big book di PPT Tulip Surabaya. PAUD Teratai, 3(3).

Mariana, S. and Zubaidah, E., 2015. Pengaruh Penggunaan Media Boneka Tangan Terhadap Keterampilan Bercerita Siswa Kelas V SD Se-Gugus 4 Kecamatan Bantul. Jurnal Prima Edukasia, 3(2), pp.166-176.

Manalu, E. and Oktaviana, M., 2014. Meningkatkan Kreativitas Bercerita Siswa Melalui Model Pembelajaran Paired Story Telling pada Mata Pelajaran Bahasa Indonesia Di Kelas VI SDN Sei Renggas. SCHOOL EDUCATION JOURNAL PGSD FIP UNIMED, 2(1).

Moleong, L. J. (2014). Metode Penelitian Kualitatif Edisi Revisi. Bandung: PT Remaja Rosdakarya Offset.

Mulyasa. (2015). Pengembangan dan Implementasi Kurikulum 2013. Bandung: Remaja Rosdakarya.

Ningsih, S., 2014. Peningkatan Keterampilan Berbicara Melalui Metode Bercerita Siswa Kelas III SD Negeri 1 Beringin Jaya Kecamatan Bumi Raya Kabupaten Morowali. Jurnal Kreatif Tadulako, 2(4).

Nurhayani, I., 2017. Pengaruh Penggunaan Metode Bercerita Terhadap Kemampuan Menyimak Siswa Pada Mata Pelajaran Bahasa Indonesia. Jurnal Pendidikan UNIGA, 4(1), pp.54-59.

Rizqillah, A.H., 2013. Metode Bercerita sebagai Model Penanaman Pendidikan Agama Islam untuk Anak Usia Prasekolah pada Area Agama Taman Kanak-kanak di Desa Bogares Kidul Kecamatan Pangkah Kabupaten Tegal. BELIA: Early Childhood Education Papers, 2(1).

Sari, I., 2012. Peningkatan Nilai-Nilai Moral Anak Melalui Bercerita, Permainan Papan Magnet di Raudhatul Athfal Baburrahman Padang Pariaman. JURNAL ILMIAH PESONA PAUD, 1(5).

Sugiyono. (2014). Metode Penelitian Pendidikan . Bandung: Alfabeta. 